The Impact of Financial Rewards on work Motivation of Operational Level Employees...

\title{
The Impact of Financial Rewards on work Motivation of Operational Level Employees: Evidence from a Leading Manufacturing Organization in Sri Lanka.
}

\author{
M. A. M. Shibly \\ T. D. Weerasinghe
}

\begin{abstract}
In any organization, financial rewards play a significant role in boosting and sustaining the work motivation of employees, which ensures employee performance. The direct effect of financial rewards on the work motivation of various types of employees is widely studied and reported. Empirical evidence and theoretical explanations are inconsistent in the literature. Therefore, it remains yet to be investigated further across different domains in the corporate atmosphere. This study was conducted to assess the impact of financial rewards on the work motivation of operational level employees in manufacturing organizations. The study was carried out as a cross-sectional, quantitative field study among a sample of 100 operational level employees, randomly selected from a manufacturing organization in Sri Lanka. The primary data was collected via a standard questionnaire which was reported as valid and reliable in previous studies. Findings show that financial rewards have a significant and a positive association $(r=$ 0.680) with the work motivation of operational level employees in manufacturing organizations. Further, findings reveal that $46.3 \%$ variation in employee work motivation $\left(r^{2}=0.463\right)$ is significantly affected by financial rewards. Moreover, financial incentives are found to be the most influential type of financial reward in determining the work motivation of operational level employees. Hence, it is recommended to manage and manipulate financial rewards to motivate employees to gain positive individual performance.
\end{abstract}

Keywords: Financial rewards; operational level employees; work motivation 


\section{Introduction}

In this era of globalization, organizations are improving business processes by adopting advanced technologies and innovations. Further, organizations try their best to hire competent employees to achieve their goals. To employ competent staff, organizations have to offer better work environments, market-based salaries, job security, and empowerment. Of all these perks and benefits, financial variables are the most important factor. On the one hand, every employee has to run his livelihood. $\mathrm{He} / \mathrm{she}$ needs financial rewards/perks to support the family. On the other hand, the management of each organization has to develop the relationship between employees and organizations to fulfill the demands of both parties. An organization expects their employees to follow the rules, policies, and regulations of the organization. In return, an employee will expect a better work environment, excellent financial rewards, and an appropriate salary. If an organization offers more financial rewards, the employees of that organization will be more motivated and satisfied. Moreover, the success of an organization is highly dependent on the employees' motivation to work. It is therefore, important for a company to ascertain what motivates its employees so that it can plan a suitable reward system and gain better results. There are two types of rewards examined in the literature; extrinsic rewards and intrinsic rewards.

Extrinsic rewards are non-job-related rewards such as pay, salary and working conditions. Gupta and Shaw (1998) concluded that financial incentives are indeed effective. According to them, not all jobs are interesting and challenging. However, in many working environments, this is not the reality. They conclude that money matters most and that it motivates us due to its symbolic and instrumental value. The symbolic value of money recaps what is assumed of it. The instrumental value of money is defined as the ends usage that can be obtained in exchange. According to Nelson (2004), when money is used to recognize employees for excellence of work, it sends a wrong signal to the employees. Accordingly, the emphasis on financial rewards might drive the employees to reach individual gains, and sometimes reduces teamwork (Gupta \& Shaw, 1998).

Motivation is defined in terms of internal and/or external forces that initiate actions that persevere until a certain goal is achieved (Daft, 2006). In business firms, these behavioral patterns are described as needs that employees are striving to satisfy through intrinsic and extrinsic rewards they receive in the workplace (Bateman \& Snell, 2007; George \& Jones, 2006). Examples of intrinsic rewards are feelings of achievement and personal growth, while extrinsic rewards include outcomes such as salary, status, job security and fringe benefits (Hellriegel et al, 2004). Moreover, employees prefer an entrepreneurial environment, excellent skills development and opportunities, high visibility in the organization, career mentoring, discretion in job creation, work-life-balance, flexibility, competitive compensations, benefits, and recognition of unique contributions (Delany \& Turvey, 2004).

Approximately 605 employees who are working in the company, were selected for the current study. The company was selected as it cited grievances within the lower level of employees, reported high labor turnover, increased absenteeism, and the deterioration of employee performance. Furthermore, the 
underlying relationships among the dependent and independent variables are inconsistent across many of the domains tested in existing literature. Hence, the present study focused on answering the following research question.

\section{What is the impact of financial rewards on the work motivation of operational level employees in manufacturing organizations?}

\section{Purpose of the study}

The purpose of this study is to assess the impact of financial rewards on work motivation of operational level employees in manufacturing firms. Furthermore, , as secondary objectives, the study focused on; (i) assessing the current level of work motivation of operational level employees in the selected domain; (ii) identifying the attitudes on the existing financial rewards system; (iii) identifying the feasible solutions to overcome the issues associated with work motivation of operational employees.

\section{Significance of the study}

This study will identify the impact of financial rewards on work motivation which, in turn, would have a large contribution to the success of the manufacturing organizations in Sri Lanka. Additionally, through identifying the key factors that affect the work motivation of operational level employees, organizations can formulate appropriate strategies that may result in an increase of employee work motivation. Additionally, through this research, the relevant stakeholders will be able to suggest to the manufacturing organizations; the work motivation issues of their employees that are not openly discussed. Furthermore, policymakers can use the finding(s) to improve their policies that will have an impact on organizational success, by assessing the level of work motivation. Moreover, the selected manufacturing organization can achieve a higher level of productivity that can raise the company profit margins.

\section{Literature review}

\section{Motivation}

The term 'motivation' is derived from the Latin word 'movere' which means 'to move'. Motivation is what moves us from boredom to interest. It is like the steering wheel of a vehicle that directs the driving. Motivation represents those psychological processes that cause the arousal, direction, and persistence of voluntary activities that are goal-oriented (Mitchell, 1982). Bartol (1998) defines motivation as a force that energizes behavior, gives direction to behavior, and underlies the tendency to persist. This definition recognizes that, in order to achieve goals, individuals must be sufficiently stimulated and energetic, must have a clear focus on what is to be achieved, and must be willing to commit their energy for a long time to realize their aims. Subsequently, a leading function of management involves urging employees to work towards organizational goals. 
Motivation constitutes a central element when going through the process of human learning. If the organization does not pose the ability to motivate its employees, the knowledge within the organization is not practically used to the maximum. Therefore, currently, it has become the aim of every organization to assess the factors that enable it to motivate its employees to continuous learning and to take advantage of their knowledge, and to ensure its survival and growth (Osteraker, 1999).

The importance of motivated employees cannot be highlighted enough in an organizational context. Motivated employees are more productive, more efficient and more willing to work towards organizational goals than the employees who are experiencing low levels of motivation. (Hunter et al, 1990). Furthermore, motivation was described by Robbins (2003) as a result of interactions between individuals and situations. Robbins (2003) stated that people have different types of needs and the interactions of situations, and the individual can either be reinforcing or hindering one's motivation.

Kreitner (2004) argued that motivation contains 'those psychological processes that cause the arousal, direction, and persistence of voluntary actions that are goal-directed'. Hence, motivation depends on certain intrinsic and extrinsic factors which in collaboration results in fully committed employees. Similarly, people are motivated when they believe that a certain need will be satisfied by achieving a goal or reward which will satisfy their needs. (Armstrong, 2009).

Motivation is the force that constantly induces to move and perform.. The most practical definition proposed by the social scientist, is that, motivation is a psychological process that inspires the stimulation, direction, and persistence of behaviour (Luthans, 2005). Many authors add a voluntary component or goal-directed emphasis on that definition (Hellriegel, 1976). Thus, motivation becomes a psychological procedure which causes the arousal, direction, and persistence of voluntary actions that are goal-directed. Incentives and rewards are the most favoured factors of employee motivation. However, employees are motivated when they achieve their needs (Spector, 1997; Milne, 2007). Intrinsic motivation and extrinsic motivation are the two branches of human motivation. Intrinsic motivation is identified as the inspiration which emanates from the inherent nature of the job, while extrinsic motivation is the incentive to do the job, driven by external factors (Kuvaas, 2006).

Extrinsic motivation can vary. An employee may perform a task due to the fear of being punished or fired, or the employee can perform an activity if that activity leads to a promotion, bonus, or growth in the future (Ryan, 2000). According to George and Jones (2012) extrinsically motivated employees work when they get a positive appraisal or reinforcerment by other people, and they are often motivated by factors such as the salary or a bonus, increment, or promotion. Similarly, Amabile (1993) mention that an extrinsically motivated employee is an individual who works when he/she engages in work to attain a goal that is apart from the work itself. Another characteristic of the extrinsically motivated employee is that they may perform their work to avoid punishment, thus the work that they are engaged in not being done for the sake of the work but for the sake of its immediate consequences. It implies that these consequences can be used to generate extrinsically motivated behaviors in employees (George, 2012). However, various 
empirical evidence and theoretical explanations confirm that intrinsic motivators can be more effective than extrinsic factors in motivating employees (Nasri \& Charfeddine, 2012; Giancola, 2014).

Work motivation is a set of energetic forces that originate both within as well as beyond an individual, to initiate work-related behavior and to determine its form, direction, intensity, and duration (Pinder, 1998). George (2012) defined work motivation as the psychological forces that determine the direction of a person's behavior in an organization, a person's level of effort, and a person's level of persistence in the face of obstacles at work.

\section{Financial Rewards}

Rewards too play an important role in determining employee motivation. Therefore, it is necessary for a manager to understand how important financial rewards are to inspire employees and motivate them. Financial rewards are identified as the most functional tool for managers to motivate employees in order to influence their behavior positively to attain organizational goals (Danish, 2010).

The significance of financial and non-financial rewards varies with the age of an employee. The nonfinancial rewards influence on work motivation to a greater extent after the pay exceeds a certain level. According to Hertzberg's [Two factor theory], there are two kinds of factors that have a strong impact on employee motivation. The hygiene factors such as pay, policies and working environment, and the motivational factors such as appreciation, recognition, caring attitude from employer and opportunities for achievements. An effective reward system can motivate the employees and enhance their productivity (Fuhrmann, 2006). Financial rewards play a critical role in enticing talented employees, however, there is only a short-term impact on their work motivation (Samodien, 2004).

In the last few decades, business organizations have focused on skills-based pay plans, by which the financial rewards of employees are paid on their new skills \& knowledge acquired, and levels of performance rather than for holding the position in the organization. With the implementation of skillsbased financial rewards, employees worked more effectively and focused on their new skills which in turn, created an 'innovation-based performance' culture. This system of skills-based pay, focuses on continuous learning and creating a learning culture, where employees' hidden competencies are also highlighted (London, 1999). However, this system of 'skills-based pay' is still based only on financial factors and economic exchange between the employee and employer, therefore, still this system is transactional. 


\section{The Nexus between Financial Rewards and Work Motivation}

Financial rewards have been recognized as a major factor that motivates employees. It is also the main expense charged on the profit and loss account of the organizations (Werner, 2004). Therefore, it has to be managed carefully. Ellis and Pennington (2004) found that direct financial rewards play a critical role in attracting talented employees, and have a combined impact on the level of work motivation of lowerlevel employees.

Financial rewards are legal obligations in the employment relationship and are critical incentives to attract and retain employees. However, the extant literature indicates that rewards transcend monetary boundaries (Chen, 1999). Monetary rewards refer to tangible objects, such as pay, bonuses, incentives, commissions, whilst non-monetary rewards are non-tangibles which include praise and recognition (Weatherly, 2002).

The importance of money as a motivator has been consistently downplayed by most behavioral scientists such as Fredrick Herzberg. In his two-factor theory; he pointed out that, the value of challenging jobs, feedback, cohesive work teams, and other nonmonetary factors stand as stimulants of work motivation. However, money is the crucial incentive which affects the work motivation because it is the vehicle by which employees can purchase the numerous need-satisfying things that they desire (Robbins et al, 2003). Researchers have found that, for the majority of the workforce in the world, regular pay is necessary to meet basic physiological and safety needs. Hence, lower-level employees are caught in the trap. Furthermore, money also performs the function of a scorecard by which employees assess the value that the organization places on their services. Thus, financial rewards are a valuable asset in the organization which in turn positively affect employees' work motivation (Langton, 2007).

Langton and Robbins (2007) mentioned that for financial rewards to motivate an individual, certain conditions must be met, that is; the type of reward must be important to an individual and should be perceived as a direct reward for performance. Especially, if it is money, the marginal amount should be perceived by the individual as significant. Therefore, for financial rewards to motivate employees at work, the marginal difference in pay increases between a high performer and an average performer or a highly skilled and low skilled should be significant.

A recent study done by Locke on four methods of motivating employees indicated that, financial rewards are the first priority among operational level employees. Such evidence demonstrates that financial rewards may not be the only motivator, but it is found to be the major factor. However, this opens up the debate that non-financial rewards such as recognition, participation in decision making and job security have a role to play in motivating employees that monetary rewards do not address. Another stream of analyses pointed out that, employees do not rate money as their main motivator. Most of the achievements are reached for reasons other than money, and it is a factor that attracts people but does 
not play a big role in retaining and motivating. Hence, they argued that sole purpose of financial rewards is to attract the employees, not for their level of motivation and retention (Loke, 1998; Amstrong, 2007; Ellis \& Pennington, 2004). Similarly, Ellis and Pennington (2004) found that direct financial rewards play a critical role in attracting talented employees. But, they have only a short-term impact on the motivation level of employees.

Armstrong (2007) cites evidence from Pfeffer (1998) and reports that employees work for money, but they work even more for meaning in their lives. Where there is no meaning of work, there is a greater loss of loyalty and commitment, and pay should therefore not be substituted for a working environment which highly considers trust, fun, and meaningfulness. This simply means that money should be used in conjunction with other motivational factors.

Moreover, Lazear (2000) mentions that that introduction of financial rewards could gain extra efforts from the employees to the extent where the marginal value added is equal to the marginal cost paid for that additional work. This shows that, financial rewards are a type of paid value to employees in return for their extra efforts exerted. Furthermore, in his research, Lazear (2000) discussed a positive relationship between employee engagement \& financial rewards and firm performance as well.

Frey (2001) conducted an econometric study investigating the effect of monetary rewards in the voluntary employment sector. Participants in the study indicates that they would decrease their volunteer service when a higher financial reward is introduced as it decreases their intrinsic motivation. This finding can be further explained using Pierce's (2003) argument. It indicates that, when financial rewards are given to individuals, they are more likely to shift their internal interests from performing a task (internal attributions) to external attributions (pay). It causes a decrease in intrinsic motivation. Thus, it has been suggested that non-financial rewards should be used appropriately (keeping a trade-off) with financial rewards to boost employees' motivation (Deci, 1972).

In the rewards-motivation relationship, the nature of rewards, especially workplace rewards, is complex. There should be a few essential characteristics of financial rewards to motivate employees such as magnitude of the rewards, types of contingencies associated with the reward, the person who administers the award, whether it is expected or individual's perceptions of fairness and satisfaction associated with the reward (Deci et al, 1999; Greenberg, 1987). Moreover, the operational level employees typically believe that increased efforts would result in increased financial rewards. If employees believe that the extra effort given will not be paid off, the employees' motivation to exert extra efforts will be limited (Jensen et.al, 2007).

Having considered the evidence in the literature, the two following hypotheses were tested, with empirical data collected from the selected manufacturing firm in Sri Lanka. 
$\mathbf{H}_{1}$ : There is a significant relationship between financial rewards and the work motivation of operational employees.

$\mathbf{H}_{2}$ : There is a significant impact of financial rewards on the work motivation of operational employees.

The aforementioned relationship is depicted in figure 01 , in which work motivation is considered as the dependent (outcome) variable and financial rewards as the independent (predictor) variable.

Figure 01: Conceptual Framework of the Study

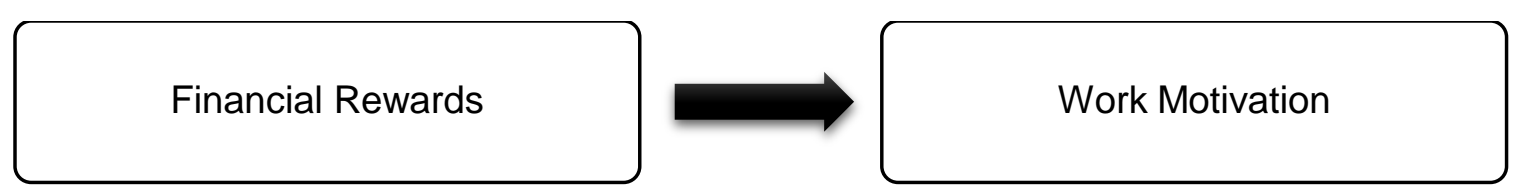

Source: Authors (2019)

\section{Materials and methods}

As the current study is an explanatory study as it intends to test the advanced hypotheses and the established relationships. Furthermore, this study intends to find the cause and effect relationship. Moreover, this is a cross-sectional study where the researcher's interference is minimum. As the total number of respondents in the population is known, the simple random sampling technique would be more appropriate to be used in selecting a representative sample. A total of 100 operational level employees were selected randomly from a leading manufacturing organization in Sri Lanka as the sample for the present study, which accounts for approximately $10 \%$ of the population. Hence, the unit of analysis was at the individual level.

Data was collected through a self-administered, standard questionnaire that has met the accepted standards of validity and reliability. Primary data collection was conducted through a questionnaire survey. It was conducted within the last two weeks of June 2018. The survey questionnaire was adopted based on the measurement scale developed by Mikander (2010) which is tested and validated widely by previous scholars in the current research domain.

The survey questionnaire comprises of two sections. Section I includes four demographic questions relating to gender, marital status, age group, and monthly income of the respondent. Section II includes twenty (20) items to assess the constructs; financial rewards and work motivation. Negatively coded items were tagged with a round sign to recognize them easily in data entering and screening. All the items in section II were put on a scale ranging from 'always to never'; anchoring on a five-point Likert scale adopted as per the original measurement scale of Mikander (2010). 
The Impact of Financial Rewards on work Motivation of Operational Level Employees...

Data was analyzed using Statistical Package for Social Sciences (SPSS) and Excel. Frequency analysis, correlation test, and regression analysis were performed to analyze data; to test the advanced hypotheses and to make conclusions.

Table 01: Descriptive Statistics - Financial Rewards

\begin{tabular}{|c|c|c|c|c|}
\hline \multicolumn{3}{|l|}{ Variable } & \multirow{2}{*}{$\begin{array}{r}\text { Statistic } \\
2.8400 \\
\end{array}$} & \multirow{2}{*}{$\begin{array}{r}\text { Std. Error } \\
.08298 \\
\end{array}$} \\
\hline \multirow[t]{12}{*}{ Financial Rewards } & Mean & & & \\
\hline & $95 \%$ Confidence Interval for Mean & Lower Bound & 2.6753 & \\
\hline & & Upper Bound & 3.0047 & \\
\hline & Median & & 2.7857 & \\
\hline & Variance & & .689 & \\
\hline & Std. Deviation & & .82984 & \\
\hline & Minimum & & 1.14 & \\
\hline & Maximum & & 4.71 & \\
\hline & Range & & 3.57 & \\
\hline & Interquartile Range & & 1.29 & \\
\hline & Skewness & & .075 & .241 \\
\hline & Kurtosis & & -.626 & .478 \\
\hline
\end{tabular}

Source: Survey Data, 2019

\section{Results and discussion}

The final sample of the current study $(n=100)$ consisted of $35.0 \%$ of males and $65.0 \%$ females. Further, $59.0 \%$ of operational level employees in the sample were married, and the remaining $49.0 \%$ were single. The majority, approximately $91.0 \%$ of the respondents belonged to the monthly income group between Rs. 15,000 - Rs. 30,000 . Only $6.0 \%$ belonged to the monthly income within Rs. 15,000 , and the rest $3.0 \%$ belonged to the monthly income group of over Rs.30, 000 per month. 
As depicted in table 01 and table 02, the mean values for two variables indicate a moderate behavior (as the mean depicts a value between 2 and 3 ) of those constructs. Similarly, the values obtained for standard deviation lies between the required range of -2 and +2 , indicating a normal behavior of the primary data set. Hence, the screened primary data set was forwarded for further analysis.

Table 02: Descriptive Statistics - Work Motivation

\begin{tabular}{|c|c|c|c|c|}
\hline \multicolumn{3}{|l|}{ Variable } & \multirow{2}{*}{$\begin{array}{r}\text { Statistic } \\
2.8408 \\
\end{array}$} & \multirow{2}{*}{$\begin{array}{r}\text { Std. Error } \\
.0681 \\
\end{array}$} \\
\hline \multirow[t]{12}{*}{ Work Motivation } & Mean & & & \\
\hline & \multirow[t]{2}{*}{ 95\% Confidence Interval for Mean } & Lower Bound & 2.7055 & \\
\hline & & Upper Bound & 2.9760 & \\
\hline & Median & & 2.7692 & \\
\hline & Variance & & .464 & \\
\hline & Std. Deviation & & .68150 & \\
\hline & Minimum & & 1.54 & \\
\hline & Maximum & & 4.85 & \\
\hline & Range & & 3.31 & \\
\hline & Interquartile Range & & .77 & \\
\hline & Skewness & & .316 & .241 \\
\hline & Kurtosis & & .339 & .478 \\
\hline
\end{tabular}

Source: Survey Data, 2019

\section{Correlation Analysis}

Table 03: Correlation

\begin{tabular}{|ll|r|r|}
\hline & & $\begin{array}{c}\text { Financial } \\
\text { Rewards }\end{array}$ & Work Motivation \\
\hline Financial Rewards & Pearson Correlation & 1 & $.680^{* *}$ \\
& Sig. (2-tailed) & & .000 \\
& $\mathrm{~N}$ & 100 & 100 \\
\hline Work Motivation & Pearson Correlation & $.680^{* *}$ & 1 \\
& Sig. (2-tailed) & .000 & \\
& $\mathrm{~N}$ & 100 & 100 \\
\hline
\end{tabular}

${ }^{\star *}$. Correlation is significant at the 0.01 level (2-tailed).

Source: Survey Data, 2019 
According to the correlation results as shown in Table 03, there is a moderate positive correlation between financial rewards and work motivation. Moreover, that association is statistically significant as the sig. value (2-tailed) is less than 0.01 . Hence, the alternative hypothesis $\left(H_{1}\right)$ is accepted concluding that, there is a positive-moderate-significant association between financial rewards and work motivation of operational level employees in manufacturing.

\section{Regression Analysis}

Table 04: Model Summary

\begin{tabular}{|c|r|r|r|r|}
\hline Model & $\mathrm{R}$ & $\mathrm{R}$ Square & \multicolumn{1}{c|}{$\begin{array}{c}\text { Adjusted R } \\
\text { Square }\end{array}$} & $\begin{array}{l}\text { Std. Error of the } \\
\text { Estimate }\end{array}$ \\
\hline 1 & $.680^{\mathrm{a}}$ & .463 & .457 & .50215 \\
\hline
\end{tabular}

a. Predictors: (Constant), Financial Rewards

Source: Survey data, 2019

Table 05: ANOVA

\begin{tabular}{|ll|r|r|r|r|r|}
\hline \multicolumn{1}{|c|}{ Model } & Sum of Squares & $\mathrm{df}$ & Mean Square & F & Sig. \\
\hline 1 & Regression & 21.269 & 1 & 21.269 & 84.349 & $.000^{\mathrm{b}}$ \\
Residual & 24.711 & 98 & .252 & & \\
Total & 45.979 & 99 & & & \\
\hline
\end{tabular}

a. Dependent Variable: Work Motivation

b. Predictors: (Constant), Financial Rewards

Source: Survey data, 2019

Table 06: Coefficients

\begin{tabular}{|c|c|c|c|c|c|c|}
\hline \multirow{2}{*}{\multicolumn{2}{|c|}{ Model }} & \multicolumn{2}{|c|}{ Unstandardized Coefficients } & $\begin{array}{l}\text { Standardized } \\
\text { Coefficients }\end{array}$ & \multirow{2}{*}{$\mathrm{t}$} & \multirow{2}{*}{ Sig. } \\
\hline & & B & Std. Error & Beta & & \\
\hline \multirow[t]{2}{*}{1} & (Constant) & 1.254 & .180 & & 6.975 & .000 \\
\hline & Financial Rewards & .559 & .061 & .680 & 9.184 & .000 \\
\hline
\end{tabular}

a. Dependent Variable: Work Motivation

Source: Survey data, 2019

In the model summary shown in Table 04 , the $\mathrm{R}$ Square is .463. This means that financial reward has an impact of $46.3 \%$ on the work motivation of employees. Further, that impact is significant as the sig. value in the ANOVA, depicted in Table 05, is less than 0.05. Hence, the alternative hypothesis $\left(\mathrm{H}_{2}\right)$ is also 
accepted, concluding that, financial rewards significantly affect the work motivation of operational level workers in manufacturing.

Table 06 presents the coefficients of linear regression. Both the constant and slope of the regression equation are statistically significant. Furthermore, according to the residual analysis of the regression test, the originated model is fitted sufficiently to predict future scenarios in similar contexts. Given the significant support from the above statistical claims, it could be concluded that the $\mathrm{H}_{2}$ is accepted and $\mathrm{H}_{0}$ is rejected. It is said to be that, financial rewards significantly impact the work motivation of operational level workers in manufacturing sector organizations.

\section{Discussion of Findings}

The findings show that financial rewards were significantly and positively associated with the work motivation of operational level employees. The study found a direct relationship. The impact relating to financial rewards and work motivation has been long validated in several domains. For example, Ellis and Pennington (2004) found that financial rewards play a critical role in attracting talented employees, motivating them to perform, and in retaining them. Lazear (1986) suggested that by adding financial rewards to the compensation package of lower-level employee for the sake of motivation, organizations can attract more appropriate and contented workers. Similarly, Werner (2004) stated that, irrespective of any demographic variable and the level of education of a person, financial rewards have been recognized as a major motivator of employees. Nelson (2004) found in a research that $78 \%$ of employees responded that it was very or extremely important to be recognized by their managers when they do good work through a financial benefit. All these empirical evidences comply with the findings of the current research.

Armstrong (2007) further argued that, the more reinforcing the reward is, the more it improves intrinsic interest as well. Bates (2006) recommended for money to motivate, 'merit pay rises' must be at least seven percent of the base pay for employees to perceive them as motivating to go an extra mile at work. However, Armstrong (2007) challenged what he calls the 'behaviorists doctrine' about money and motivation. He claimed that no controlled scientific study has found a long-term enhancement of the quality of work as a result of any reward system. Hence, it is noted that the current researcher has received similar results as found in extant literature. 


\section{Conclusion}

The current research is typical in its interpretation of financial rewards concerning work motivation and sheds practical insights explaining the impact of financial rewards on work motivation. According to the findings of the research, it could be concluded that there is a significant impact of financial rewards on work motivation. However, the association among them is moderate. Hence, financial rewards in the domain are/will be a significant predictor / manipulator to obtain the outcome of the work motivation of operational level employees only up to a minimum extent.

\section{Recommendations}

Many reward systems have been developed and used in the Sri Lankan manufacturing companies during the last two decades. All decisions on rewards generated from the top management; the employees did not have any influence on the development process. Hence, the researchers of the current study would suggest that the organizations should include the employees in the decision-making process and the development of the rewards systems. This could be done by allowing the employees to frequently provide feedback on the financial rewards systems. Perhaps, this could be done together with the development discussions that take place once a year between the management and the employees. Moreover, organizations should highly emphasize on the 'basic pay' and 'incentives' rather than welfare, as operational level employees are significantly sensitive to those two components of financial rewards. Similarly, researchers would suggest that, the companies should implement and develop a proper mechanism to frequently monitor the financial rewards system while keeping a trade-off among financial and non-financial rewards. Furthermore, in such a mechanism, the organizations should focus on the implementation and development of reasonable and transparent performance standards linking it with the financial rewards that may increase the worth of receiving those rewards, which in turn appropriately motivates the receivers.

\section{Direction for Future Research}

The sample size of this research can be increased, in order that, the generalizability of the findings will be improved. Only the financial rewards were considered as the independent variable in the conceptualized research model as per the requirements and set objectives of the current study. However, it is suggested that, including the non-financial rewards might increase the strength of the research model in further studies. Moreover, a cross-validation of the results in divergent organizations and divergent industries will add more value to the insights of the present study. Furthermore, it is suggested that future studies should collect data from multiple sources other than employees, such as managers, team leaders/project leaders, subordinates, clients, and comparatively from a bigger sample as it would provide more solid and broader insights regarding the relationship between the variables considered in this research. 
However, within its limitations, the current study successfully achieved its set objectives and opened new possibilities for social \& management studies in the future. Hence, it is expected that future studies in other industries/markets/countries considering more variables, will add more value to the present research work in the field of Human Resource Management and Development.

\section{References}

Armstrong, M. (2009). A Handbook of Human Resource Management Practice (11 Ed.). Cambridge, UK: Kogan Page Limited.

Arnold, J. (2010). Work Psychology: Understanding Human Behavior on the Workplace. (5 Ed.). Harlow, UK: Prentice Hall.

Bateman, T. (2007). Management: Leading \& collaborating in a competitive world. Boston: McGraw-Hill. Bratton, J. (2007). Human Resource Management: Theory and Practice. (4th ed.). New York: Palgrave Macmillan.

Chen, C. F. (1999). Do rewards benefit the organization? The effects of reward types and the perceptions of diverse $R \& D$ professionals. Transactions on Engineering Management, 47-55.

Churchill, G. A. (1993). Sales Force Management. Irwin: Homewood, IL.

Danish, R. (2010). Impact of reward and recognition on job satisfaction and motivation: An empirical study from Pakistan. International journal of business and management, 159.

Deci, E. (1972). The effects of contingent and non-contingent rewards and controls on intrinsic motivation. Organizational Behavior and Human Performance, 217-229.

Frey, B. (2001). Motivation crowding theory: A survey of empirical evidence. Journal of Economic Surveys, 589611.

Fuhrmann, T. (2006). Motivating Employees. Advances in Diary Technology, 93-101.

George, J. (2006). Contemporary management: Creating value in organizations. Boston: McGraw-Hill.

Greenberg, J. B. (2003). Behavior in organization: Understanding and managing the human side of work", 6th ed, Prentice Hall, Saddle River, New Jersey.

Gupta, N. \&. (1998). Let the Evidence Speak: Financial Incentives Are Effective!! Compensation and Benefits Review, Vol. 30 No. 2, 26-30.

Heathfield, S. M. (2013, January 13). Retrieved from http://humanresources.about.com, on $2^{\text {nd }}$ March 2019.

Hellriegel, D. J. (2004). Management. Cape Town, South Africa: Oxford University Press.

Herzberg, F. (1968). "One more time: how do you motivate employees?" Harvard Business Review, 53-62.

Jensen, D. \& McMullen, T. \&. (2007). The Manager's Guide to Rewards. USA: Hay Group Inc.

Kreitner, R. (2004). Organizational Behavior, 6th Edition. Boston: McGraw-Hill, Irwin.

Kuvaas, B. (2006). Work performance, affective commitment, and work motivation: The roles of pay administration and pay level. Journal of Organizational Behavior, 365-385.

Kohn A., (1993). Why Incentive Plans Cannot Work. Harvard Business Review. Vol. 71, 54-63.

Laakso, L. (2012). Case Study: The Impact of Financial and Non-financial Rewards on employee motivation. International Business Management. 
The Impact of Financial Rewards on work Motivation of Operational Level Employees...

London, M. (1999). Empowered self-development and continuous learning. Human Resource Management, 38, 3-15.

Markova, G. \& Ford, S. (2011). Is money the panacea? Rewards for Knowledge Workers. International Journal of Productivity and Performance Management, 813-823.

Mitchell, T. (1982). Motivation: New Direction for Theory, Research, and Practices. Academy of Management Review, pp. 80-8.

Mowday, R. (1998). Reflections on the study and relevance of organizational commitment. Human resource Management review, 387-401.

Nelson, B. (2004). Misunderstanding rewards hampers motivation. Canadian HR reporter, Vol. 17, 14 and 17.

Pfeffer, J. (1998). Six Dangerous Myths about Pay. Harvard Business Review, 109-119.

Peterson, M. (2003). Cultural socialization as a source of intrinsic work motivation,. Group and Organizational Management, Vol. 28, pp. 185-216

Ramlall, S. (2004). Review of employee motivation theories and their implications for employee retention within organizations. Journal of American Academy of Business, 52-63.

Ryan, R. M. (2000). Intrinsic and Extrinsic Motivations: Classic Definitions and New Directions. Contemporary Educational Psychology, 54-67.

Robbins, S. (2003). Organizational Behavior 10 Ed. Upper Saddle River, New Jersey: Prentice Hall. .

Squires, G. (2001). Management as a Professional discipline. Journal of Management Studies, 38(4), $473-487$.

Thompson, A. S. (2005). Crafting and executing strategy: The quest for competitive advantage. New York: McGraw-Hill Irwin.

Trevor, J. (2008). Can pay be strategic? In Rethinking Reward. Basingstoke: Palgrave Macmillan.

Van Knippenberg, D. (2000). Work motivation and performance. A social identity perspective. International Association for Applied Psychology, 357-371.

Wang, Y. (2004). Observations on the Organizational Commitment of Chinese Employees: Comparative Studies of State-Owned Enterprises and Foreign-Invested Enterprises. The International Journal of Human Resource Management, 649-664.

Weatherly, R. (2002). Effects of external rewards on internal motivation and job satisfaction. Master's thesis. Retrieved on 10, April 2018.

Werner, S. (2004). Recent Compensation Research: An eclectic review. Human Resource Management Review, 201-227. 